\title{
MUSLIM TIONGHOA SEBAGAI LIYAN DALAM KONSEP UKHUWWAH ISLAMIYAH
}

\author{
Oleh: Ade Irma \\ Dosen Jurusan Ilmu Komunikasi \\ Fakultas Ilmu Sosial dan Ilmu Politik \\ Universitas Tekhnologi Yogyakarta \\ E:mail: layang2an@gmail.com
}

\begin{abstract}
Tionghoanesse moeslem is part of Tionghoa's ethnic, but instead of known as a Tionghoa, they do not know as a part of moeslem community. During the Orde Baru era, the Tionghoa's having a repression from government. Back than they were forced to be 'Indonesian' with various total assimilation programs. While Tionghoa's ethnic become minority and was being repressed, the Tionghoanesse moeslem community was being more repressed. As we know, the Tionghoa's moeslem community is a minor people on minority group, so they are having a double difficulty to face Indonesia's social and cultural costum.

During the reformation era, government withdrawing the rules that suffers them, in this era Tionghoa's ethnic having their own freedom to express them self and having their own Tionghoa's identity. PITI Surabaya, as an organization which collecting Tionghoa's moeslem community in Surabaya, has various ways to break the stigma about Tionghoa's moeslem community. Although, PITI Surabaya has tried various ways to show their exsistence but, the discrimination on them are still on the way until today.

The focus on this paper is how PITI Surabaya with all their various ways in reducing discrimination can survive the contestation on their identity's construction and discrimination among other moeslem's community in Surabaya.
\end{abstract}

Key words: PITI Surabaya, Tionghoa's moeslem community, discrimination, constructing identity. 


\section{A. Latar Belakang}

'Karena Islam juga keyakinan kami, dan kami adalah muslim Tionghoa'.

Ucapan tersebut dinyatakan dengan keyakinan yang dapat dirasakan oleh penulis ketika proses wawancara berlangsung dengan Abah Djoko, selaku ketua PITI Surabaya. Islam bagi etnis Tionghoa sendiri bukanlah hal asing yang tidak dikenal oleh leluhur mereka. Bahkan, Laksamana Cheng Ho tercatat dalam sejarah sebagai laksamana muslim yang memiliki pengaruh besar pada peradaban dunia. Bukan hal yang berbeda bagi mereka menjadi muslim, namun justru hal tersebut menjadi tidak biasa bagi warga lain yang berasumsi bahwa etnis Tionghoa identik sebagai pemeluk keyakinan Tri Dharma, Kristen, Katholik, maupun Budha. Munculnya asumsi tersebut membuat keberadaan muslim etnis Tionghoa seolah mengalami peliyanan dari pemeluk Islam lainnya.

Berawal dari munculnya asumsi pada masyarakat muslim etnis Tionghoa, kerukunan warga Tionghoa yang dimotori oleh bapak Anton Medan mendirikan organisasi PITI di Jakarta. PITI (Persatuan Tionghoa Islam Indonesia) adalah organisasi etnis Tionghoa muslim yang berbasis sosial dan telah berdiri sejak tahun 1961, memposisikan diri sebagai satusatunya organisasi etnis Tionghoa muslim di Indonesia. PITI dalam perkembangannya telah tersebar di seluruh wilayah Indonesia dan merepresentasikan diri sebagai wajah indentitas muslim Indonesia. PITI Surabaya, sebagai bagian dari PITI Indonesia yang menjadi fokus dalam penelitian ini memiliki kekhasan yang tidak dimiliki oleh PITI lainnya. PITI Surabaya, sebagai organisasi social etnis Tionghoa Muslim memiliki jaringan luas dan kiprah aktif dan sinergitas yang baik dengan elemen-elemen lain yang ada di Surabaya. Sinergitas PITI dengan elemen lainnya di Surabaya nampak pada antusiasme dan keikutsertaan elemenelemen lain yang berpartisipasi dalam setiap acara yang diadakan oleh PITI Surabaya. PITI Surabaya sendiri juga dinilai mampu dalam membangun harmoni kerukunan sehingga keberadaannya sebagai salah satu elemen penyokong kerukunan umat beragama dipandang cukup berpengaruh di wilayah Surabaya.

Pembahasan pada tulisan ilmiah ini justru berfokus pada bagaimana PITI Surabaya mampu menjadi wadah etnis Tionghoa muslim dalam beraktifitas secara keagaman dan secara sosial. Hal tersebut menjadi menarik untuk dikaji lebih lanjut sebab PITI Surabaya dalam menjaga eksistensinya mengalami berbagai kontestasi dan diskriminasi. PITI Surabaya sebagai wadah muslim etnis Tionghoa tidak hanya berusaha untuk menjembatani komunikasi internal antar muslim Tionghoa juga berperan sebagai penjembatan muslim Tionghoa dengan elemen sosial lainnya. 
Peliyanan yang muncul bagi penganut muslim Tionghoa di Surabaya menjadi menarik untuk dianalisis lebih lanjut. Dalam peliyanan sesungguhnya muslim Tionghoa Surabaya juga mengalami beragam pergulatan untuk menstabilkan posisi identitas mereka.

\section{B. Etnis Tionghoa Muslim, Sejarah Panjang, Kiprah dan Represi Terhadapnya}

Islam, bagi etnis Tionghoa bukan menjadi hal baru yang asing bagi mereka. Masyarakat Tionghoa sangat mengenal siapa Laksamana Muhammad Cheng Hoo, yang telah menjadi ikon bagi mereka. Laksamana Cheng Hoo (Zheng He), tercatat dalam sejarah sebagai salah seorang admiral muslim yang telah berhasil menjadi duta Islam kala itu. Cheng Hoo (Zheng $\mathrm{He}$ ) memulai pelayarannya di tahun 1405, berlayar selama 29 tahun dan berhasil melalui wilayah Asia hingga Afrika, selama pelayarannya tidak hanya berhasil membangun jaringan perdagangan, Cheng Hoo (Zheng $\mathrm{He}$ ) juga telah berhasil menyebarkan Islam lebih luas. Warisan Cheng Hoo (Zheng He) yang termasyur hingga kini salah satunya adalah jalur perdagangan yang ditempuhnya dikenal sebagai jalur sutra.

Jalur sutra, seperti yang diketahui oleh khalayak adalah jalur perdagangan yang dilalui oleh Cheng Hoo (Zheng $\mathrm{He}$ ) meliputi beberapa rute perdagangan, salah satunya yakni wilayah malaka hingga Asia Tenggara. Jalur sutra, yang ditempuh oleh Cheng Hoo (Zheng $\mathrm{He}$ ), berhasil memetakan wilayah dunia dari Tiongkok hingga semenanjung Afrika. Pemetaan tersebut bahkan menjadi rujukan pelayaran selama beberapa waktu, melalui peta yang dibuat oleh Cheng Hoo (Zheng He) jalur perdagangan menjadi lebih dapat spesifik untuk dilalui dan jenis bahan pun lebih spesifik untuk dapat memenuhi kebutuhan partner dagang mereka $(\mathrm{Fu}$, Foo, Siew : 2005)

Namun, banyak dari khalayak yang tidak mengenali nama lain dari jalur sutra yang sudah termasyhur tersebut. Kennedy, menyatakan dalam bukunya The Great Arab Conquest (Kennedy : 2007) menyebutkan bahwa jalur sutra yang dilewati oleh Cheng Hoo (Zheng $\mathrm{He}$ ) membawa spirit Islam yang kental. Hingga ke wilayah semenanjung Malaka dan Asia Tenggara kemudian jalur tersebut dikenal sebagai jalur santri. Hal tersebut bukan sebuah dugaan semata, namun seperti diketahui, kapal ekspedisi Cheng Hoo (Zheng $\mathrm{He}$ ) tidak hanya memuat beragam barang perdagangan, didalamnya juga mengangkut beberapa pemeluk dan pemuka agama. Terbukanya jalur perdagangan melalui jalur sutra yang digagas Cheng Hoo (Zheng He) juga berdampak pada hubungan erat yang terjalin dengan kerajaan Arab Saudi kala itu.

Hubungan tersebut kemudian mempengaruhi bagaimana Cheng Hoo (Zheng He) mengembangkan hubungan yang lebih dalam dengan penguasa di wilayah semenanjung 
Malaka, khususnya di wilayah Jawa. Tercatat keberadaan Cheng Hoo (Zheng He) di Jawa bahkan membuahkan sebuah kerjasama lebih erat melalui perkawinan antara Putri Campa dengan Raja Majapahit kala itu ${ }^{1}$. Perkawinan tersebut tidak hanya bermuatan bisnis semata, namun jalinan kekerabatan yang muncul dari perkawinan tersebut menjadi cikal bakal penyebaran Islam melalui para wali yang termasyhur di Indonesia - khususnya - dan semenanjung Malaka - umumnya -.

Dari perkawinan tersebut, memiliki keturunan yang menjadi bagian dari wali songo yakni Raden Patah ( Sunan Kalijaga), Raden Rahmat ( Sunan Ampel ), Raden Muhammad Ainul Yakin ( Sunan Giri). Kiprah para sunan dan kontribusinya bagi Islam, khususnya di wilayah Jawa hingga sekarang masih langgeng terdengar dan memiliki beragam peninggalan yang rutin diziarahi oleh pemeluk Islam. Namun diantara nama besar para sunan yang tersohor, pemeluk Islam kini justru tidak menaruh atensi pada kontribusi warga muslim Tionghoa yang juga membersamai bahkan merupakan bagian dari syiar Islam di wilayah Jawa - khususnya - dan semenanjung malaka. Kiprah muslim Tionghoa sendiri seolah ternafikan, dan bahkan kontribusi yang telah mereka munculkan seolah tidak terlacak sebagai bagian dari pembangun peradaban Islam. Etnis muslim Tionghoa, seolah menjadi bagian yang tidak terdeteksi dan tidak diketahui kiprah dan keberadaannya.

Tidak hanya dalam penyebaran Islam di Jawa dan semenanjung malaka, keberadaan etnis muslim Tionghoa juga mewarnai kebudayaan yang ada di wilayah Jawa dan semenanjung malaka. Salah satu kontribusi warga muslim Tionghoa adalah produk batik tiga negeri di wilayah Lasem

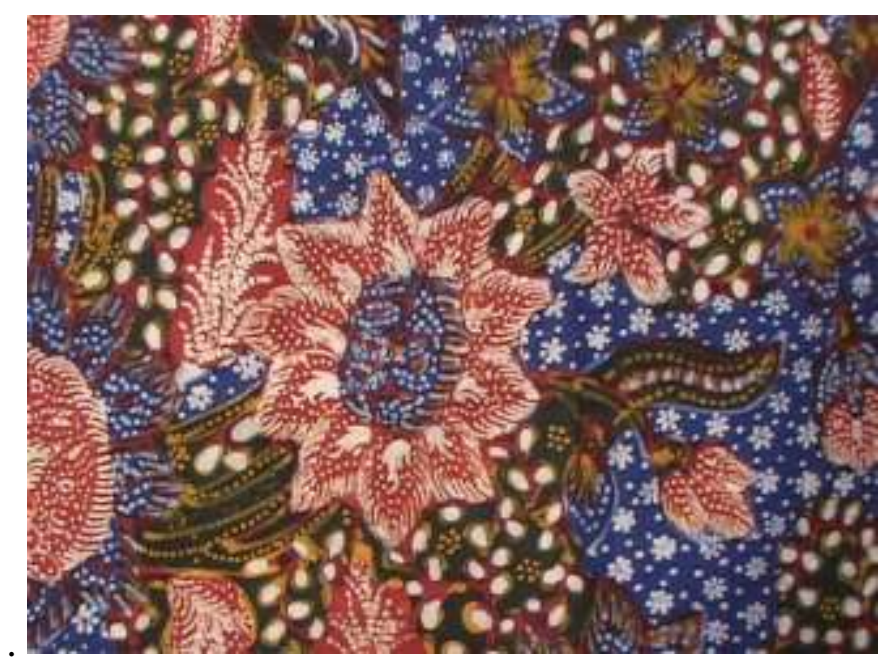

Batik Tiga Negeri

\footnotetext{
${ }^{1}$ Zheng He, Wikipedia
} 
Batik Tiga Negeri adalah hasil akulturasi dari budaya Tionghoa, Belanda dan Jawa, masing-masing warna merepresentasikan budaya yang berakulturasi. Coklat sebagai representasi suku Jawa, Merah sebagai representasi etnis Tionghoa dan biru sebagai representasi Belanda. Peranan etnis Tionghoa yang muncul dalam representasi batik tiga negeri juga tidak begitu diketahui oleh khalayak luas.

Bukan hanya pada sisi produk budaya, kiprah masyarakat muslim Tionghoa juga muncul dibeberapa peninggalan sejarah salah satunya adalah pada kesenian musik yang diadaptasi hingga sekarang yakni, gambang kromong. Gambang Kromong adalah kesenian yang dikenali khalayak sebagai kesenian khas betawi, sedikit dari mereka yang mengetahui bahwa kesenian ini memiliki pengaruh kental dari kesenian khas Tiongkok.

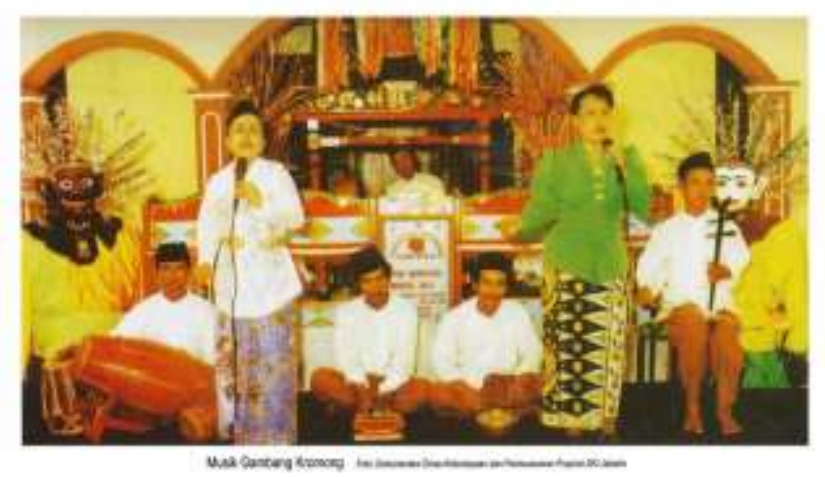

seorang pemimpin komunitas Tionghoa yang diangkat oleh Belanda (kapitan Cina) bernama Nie Hoe Kong (masa jabatan 1736-1740)².

Tangga nada yang digunakan dalam gambang kromong adalah tangga nada pentatonik China, sering disebut Salendro Cina atau Salendro mandalungan.

Orkes gambang kromong merupakan perpaduan yang serasi antara unsur-unsur pribumi dengan unsur Tionghoa. Secara fisik unsur etnis Tionghoa tampak pada alat-alat musik geseknya: sukong, tehyan, dan kongahyan. Perpaduan kedua unsur kebudayaan tersebut tampak pula pada perbendaharaan lagu-lagunya.

Kiprah etnis Tionghoa yang muncul sebagai bagian dari asimilasi produk budaya dan berkembang pesat sebagai bagian dari budaya Islam maupun budaya Indonesia menjadi tidak teraba dan tidak banyak diketahui oleh khalayak. Hal tersebut tidak lepas dari bagaimana rejim penguasa memberi ruang bagi etnis muslim Tionghoa untuk eksis dalam ranah sosial. Bukan menjadi rahasia, jika etnis Tionghoa mengalami tindakan represi di era rejim Soeharto khususnya. Dalam rejim ini, pemerintah menekankan kebijakan politik asimilasi untuk

\footnotetext{
${ }^{2}$ Jakarta Encyclopedia
} 
'mengindonesiakan' etnis Tionghoa. Visibilitas etnis Tionghoa sendiri hampir dikatakan tidak ada saat rejim orde baru berkuasa (Budianta: 2004; Lindsey: 2005).

Represi terhadap kiprah etnis Tionghoa, secara umum juga terjadi pada etnis muslim Tionghoa, rejim yang berkuasa kala itu bahkan memunculkan pembauran total guna untuk menafikan keberadaan etnis Tionghoa, baik secara entitas maupun secara budaya. Salah satu bentuk pembauran total yang terjadi kala itu yakni, penggantian nama-nama Tionghoa menjadi nama-nama yang lebih 'terasa' Indonesia. Hal tersebut bahkan diatur secara resmi melalui Inpres no.14 tahun 1967. Represi terhadap etnis Tionghoa - umumnya - dan Tionghoa muslim - khususnya - berdampak pada konstruksi identitas dan representasi identitas mereka sebagai etnis Tionghoa di Indonesia. Pembahasan pada hal ini akan dilakukan oleh penulis pada bagian selanjutnya dari tulisan ini.

\section{Identitas Muslim Tionghoa: Sebuah Kontestasi dan Insekuritas dalam wacana Sosial}

Sebelum membahas perihal identitas muslim Tionghoa, penulis ingin mengawali dengan menyoroti bagaimana identitas ketionghoaan mereka muncul di Indonesia. Hal tersebut dipandang krusial sebab identitas Tionghoa sendiri mengalami beberapa konstruksi di berberapa era rezim yang berkuasa. Identitas Tionghoa berjalin kelindan dan berkaitan erat dengan kebijakan politik yang kemudian memunculkan makna identitas Tionghoa bagi khalayak.

Identitas ketionghoan sendiri adalah sebuah konstruksi cair dimana ianya kemudian menjadi sebuah konstruksi hybrid. Ang menjelaskan bahwa perspektif yang ia pakai untuk membahas identitas ketionghoaan adalah dari sudut pandang hibriditas, yaitu posisi ambigu antara "bukan ini bukan itu,"atau sekaligus "keduanya". Ang kemudian menyebutkannya sebagai "kebersamaaan dalam perbedaan" (Ang, 2005: 30). Hal tersebut nampak pada bagaimana konstruksi identitas Tionghoa muncul dalam ranah sosial.

Selama 32 tahun etnis Tionghoa di Indonesia mengalami pembungkaman oleh rejim yang berkuasa, hal ini menjadi pematik munculnya kebencian pada etnis Tionghoa. Puncak tindakan diskriminatif yang terejawantahkan dalam tindakan kebencian tersulut pada saat kerusuhan reformasi tahun 1998 lalu. Munculnya tindakan anarkis pada etnis Tionghoa, bukan sebuah tindakan yang dapat dipandang tunggal. Hal tersebut tidak lepas stigma identitas etnis Tionghoa yang dicitrakan sebagai orang kaya yang menguasai perekonomian 
di Indonesia. Diskriminasi atas diri mereka semakin menjadi dan mengakibatkan eksodus besar-besaran ketika kerusuhan 1998 terjadi.

Menjadi Tionghoa dalam ranah sosial di Indonesia bukan perkara mudah, seperti yang telah disinggung pada bagian sebelumnya, visibilitas etnis Tionghoa mengalami pembatasan bahkan pada kondisi tertentu seolah mengalami pembungkaman yang di dukung penuh oleh rejim yang berkuasa saat itu. Hal tersebut berlaku bagi keseluruhan etnis Tionghoa tanpa memandang keyakinan, maupun status sosial individu etnis Tionghoa. Berbicara tentang masalah Tionghoa di Indonesia, Christian Chua (2004) mengatakan bahwa identitas Tionghoa di Indonesia diatur oleh negara, sejalan dengan apa yang dikatakan oleh Ien Ang bahwa identitas adalah by consent. Artinya, identitasnya sebagai orang Tionghoa sangat cair

Kadang-kadang ia menjadi Tionghoa bila diperkenankan/diperlukan oleh negara. Chua mengatakan hal yang hampir sama dengan Ang, bahwa pemerintah orde baru telah melakukan tiga upaya penting yang pejoratif terhadap orang Tionghoa, yaitu: marjinalisasi, diskriminasi, dan stigmatisasi. Pertama, marjinalisasi terhadap orang Tionghoa justru berlangsung dengan cara mereka dinetralisasi melalui program pembauran total. Kedua, untuk menghindari agar mereka tetap bisa dipantau, mereka didiskriminasi, dan dengan demikian mengingkari politik asimilasi. Ketiga, orang Tionghoa yang minoritas diberi stigma sebagai orang kaya. Dengan demikian dapat dikatakan, bahwa identitas sosial orang Tionghoa (ketionghoaan) juga diwarnai konten dan proses sejarahnya oleh negara (baca: pemerintahan Orde Baru) untuk mengatur mereka dalam kehidupan bernegara. Kajian Chua ini mungkin akan dapat menjadi kontribusi tersendiri dalam melihat stereotipisasi objek materi dalam penelitian saya. Walau Chua tidak membahas secara mendalam stereotipisasi, kajiannya dapat menjadi rujukan awal untuk melihat bagaimana orang Tionghoa diberi stigma dan bagaimana mereka dibentuk oleh negara di dalam perkembangan identitasnya (dikutip dari disertasi Liliek Yuwono: 20015).

Hal tersebut justru mengakibatkan munculnya beragam tindakan represi yang berdampak pada terjadinya stereotyping etnis Tionghoa di Indonesia. Etnis Tionghoa yang pada akarnya memiliki beragam perbedaan dan ciri khas, keberadaannya menjadi etnis Tionghoa yang telah dilabeli homogen oleh rejim penguasa dan konstruk sosial kala itu. Tindakan itu juga tidak lepas dari bagaimana etnis muslim Tionghoa diperlakukandi Indonesia. Dampak dari tindakan tersebut mengakibatkan identitas muslim etnis Tionghoa yang keberadaannya dalam konteks sosial seolah tidak dikenali oleh khalayak. 
Ketika menjadi entitas Tionghoa begitu sulit di rejim orde baru, maka menjadi muslim Tionghoa memiliki tingkat kesulitan yang lebih. Islam di wilayah Indonesia sendiri merupakan agama yang dianut oleh mayoritas penduduk Indonesia, namun diantara pemeluknya muncul beragam pengkotakan identitas muslim. Seperti yang diungkap oleh Abah Djoko sebagai informan, beliau menyatakan bahwa,

'Dulu (baca : era Orde Baru), orang muslim Tionghoa di Surabaya sullit untuk mendapatkan sokongan sosial. Kami bahhkan tidak bisa menjalin kerjasama antar sesama pemeluk Islam, dan kami juga tidak cukup punya beking di komunitas Tionghoa, karena komunitas Tionghoa sifatnya masih sangat terbatas keberadaannya.'

Muslim Tionghoa menjadi bagian minor dalam kelompok minoritas, mereka adalah bagian yang tidak cukup mendapat akses bahkan akses untuk sekedar beribadah. Muslim Tionghoa di Surabaya - khususnya - dan Indonesia - umumnya - terjebak pada keadaan yang bukan menjadi bagian kelompok manapun. Meski secara umum mereka diperlakukan sama oleh rejim yang berkuasa kala itu yakni sebagai etnis Tionghoa yang terdiskriminasi.

Usaha untuk menjadi ada secara sosial baru nampak menggeliat ketika rejim orde baru tidak lagi berkuasa. Etnis Tionghoa mulai melakukan beragam tindakan yang menunjukkan eksistensi ke-Tionghoaan mereka. Era reformasi telah memberi ruang pada mereka untuk muncul sebagai entitas etnis Tionghoa dan berkiprah secara sosial. Hal tersebut terjadi sebab rejim kala itu telah mencabut beberapa peraturan pemerintah yang diskriminatif terhadap mereka. Geliat warga Tionghoa mulai muncul dan berkembang cukup pesat pada era pemerintahan Gus Dur.

Pemerintahan Gus Dur kala itu menginisiasi terciptanya pluralisme yang mendorong keterbukaan dalam kehidupan berbangsa dan bernegara. Melalui Keppres No.6 tahun 2000³,

\footnotetext{
3 Menimbang:
}

a. bahwa penyelenggaraan kegiatan agama, kepercayaan, dan adat istiadat, pada hakekatnya merupakan bagian tidak terpisahkan dari hak asasi manusia;

b. bahwa pelaksanaan Instruksi Presiden Nomor 14 Tahun 1967 tentang Agama, Kepercayaan, Adat Istiadat Cina, dirasakan oleh warga negara Indonesia keturunan Cina telah membatasi ruanggeraknya dalam menyelenggarakan kegiatan keagamaan, kepercayaan, dan adat istiadatnya;

c. bahwa sehubungan dengan hal tersebut dalam huruf a dan b, dipandang perlu mencabut Instruksi Presiden Nomor 14 Tahun 1967 tentang Agama, Kepercayaan, Adat Istiadat Cina dengan Keputusan Presiden;

Menetapkan:

KEPUTUSAN PRESIDEN TENTANG PENCABUTAN INSTRUKSI PRESIDEN NOMOR 14 TAHUN 1967 TENTANG AGAMA, KEPERCAYAAN, DAN ADAT ISTIADAT CINA. 
negara kemudian mengukuhkan etnis Tionghoa dan hal-hal yang berkaitan dengan tampilan identitas baik melalui budaya maupun keyakinan menjadi bagian dari Negara Kesatuan Republik Indonesia.

Pemerintah kala itu (Gus Dur) memeberi ruang bagi warga Tionghoa untuk diakui keberadaannya oleh Negara. Pengakuan tersebut muncul berupa, antara lain : diakuinya alahh satu hari besar yang dirayakan oleh warga Tionghoa yakni Tahun Baru Imlek. Pada bulan Februari 2003, Tahun Baru Imlek dirayakan secara resmi untuk pertama kalinya oleh masyarakat Indonesia keturunan Tionghoa setelah 30 tahun lebih dilarang oleh pemerintah Indonesia. Pada saat itulah masyarakat Indonesia keturunan Tionghoa menikmati tahun baru Imlek sebagai hari libur resmi nasional. Hal ini sangat berkaitan dengan apa yang dilakukan oleh Presiden Abdurrahman Wahid pada tahun 2000 yang mendeklarasikan Imlek sebagai opsi hari libur Nasional (Retnaningsih, 2012: 9).

Selain Tahun Baru Imlek, pemerintah juga mencabut undang- undang yang sifatnya diskriminatif $^{4}$ sehingga etnis Tionghoa dapat kembali merepresentasikan identitasnya sesuai dengan apa yang mereka ingin munculkan dalam ranah sosial.

PERTAMA:

Mencabut Instruksi Presiden Nomor 14 Tahun 1967 tentang Agama, Kepercayaan, dan Adat Istiadat Cina.

KEDUA:

Dengan berlakunya Keputusan Presiden ini, semua ketentuan pelaksanaan yang ada akibat Instruksi Presiden Nomor 14 Tahun 1967 tentang Agama, Kepercayaan, dan Adat Istiadat Cina tersebut dinyatakan tidak berlaku.

KETIGA:

Dengan ini penyelenggaraan kegiatan keagamaan, kepercayaan, dan adat istiadat Cina dilaksanakan tanpa memerlukan izin khusus sebagaimana berlangsung selama ini.

KEEMPAT:

Keputusan Presiden ini mulai berlaku pada tanggal ditetapkan.

\footnotetext{
${ }^{4}$ Inpres No. 14 tahun 1967. Isi dari Inpres ini adalah : bahwa agama, kepercayaan dan adat istiadat Cina di Indonesia yang berpusat pada negeri leluhurnya, yang dalam manifestasinya dapat menimbulkan pengaruh psychologis, mental dan moril yang kurang wajar terhadap warganegara Indonesia sehingga merupakan hambatan terhadap proses asimilasi, perlu diatur serta ditempatkan fungsinya pada proporsi yang wajar. Sehingga dalam pelaksanaannya harus dilakukan dengan cara :

PERTAMA:

Tanpa mengurangi jaminan keleluasaan memeluk agama dan menunaikan ibadatnya, tata-cara ibadah Cina yang memiliki aspek affinitas culturil yang berpusat pada negeri leluhurnya, pelaksanaannya harus dilakukan secara intern dalam hubungan keluarga atau perorangan.
} 
Semangat untuk menunjukkan diri dalam ranah sosial juga dialami oleh etnis Tionghoa muslim. Geliat untuk menjadi ada dan dikenali sebagai bagian, baik NKRI maupun komunitas muslim, khususnya di Surabaya mulai semarak. Hal tersebut ditandai dengan mulai berdirinya Masjid Muhammad Cheng Ho di Surabaya pada tahun 2001 . Pendirian Masjid Muhammad Cheng Ho di Surabaya, bukan hanya sebuah usaha untuk menunjukkan eksistensi etnis Tionghoa muslim, namun juga merupakan sebuah cara komunikasi bagi khalayak Surabaya - khususnya - dan Indonesia umumnya bahwa etnis Tionghoa sendiri adalah sebuah entitas etnis yang heterogen,

'Kami perlu untuk membuat masyarakat tahu jika Tionghoa itu ngga melulu Khong hu Chu, atau Nasrani atau Budha. Tionghoa sendiri itu bermacam-macam lho, dan muslim Tionghoa juga bagian dari orang Tinghoa. Kita mesti mengabarkan pada masyarakat bahwa muslim Tionghoa tidak berbeda (baca : adat istiadatnya) dengan Tionghoa, juga tidak berbeda dengan muslim lainnya (baca : keyakinan dan peribadatannya).'

\section{-Abah Djoko -}

Muslim Tionghoa di Surabaya, melalui deskripsi yang digambarkan oleh Abah Joko ${ }^{6}$ mengalami beragam kontestasi dalam proses stabilitas identitas mereka di ranah sosial

Merujuk pada Hall (dalam Woodward, 2002 : 21), tindakan yang dilakukan untuk dalam arena kontestasi identitas adalah sebuah hal yang harus dilakukan untuk menjadi 'ada' dalam sebuah ruang sosial. Hal ini tidak terlepas dari pemahaman bahwa identitas adalah

KEDUA:

Perayaan-perayaan pesta agama dan adat istiadat Cina dilakukan secara tidak menyolok di depan umum, melainkan dilakukan dalam lingkungan keluarga.

KETIGA:

Penentuan katagori agama dan kepercayaan maupun pelaksanaan cara-cara ibadat agama, kepercayaan dan adat istiadat Cina diatur oleh menteri Agama setelah mendengar pertimbangan JaksaAgung (PAKEM).

KEEMPAT:

Pengamanan dan penertiban terhadap pelaksanaan kebijaksanaan pokok ini diatur oleh Menteri Dalam Negeri bersama-sama Jaksa Agung.

KELIMA:

Instruksi ini mulai berlaku pada hari ditetapkan.

\footnotetext{
${ }^{5}$ Dalam buku Sekilas Tentang Masjid Muhammad Cheng Ho Surabaya, cetakan ke - 8 .

${ }^{6}$ Abah Joko adalah Ketua PITI Surabaya, beliau adalah sekelompok kecil penggiat yang pertama kali membangun organisasi PITI Jawa Timur, khususnya Surabaya.
} 
sebuah konstruksi cair dimana representasi terhadapnya adalah sebuah konstruksi melalui diferensiasi. Usaha muslim Tionghoa melalui berbagai cara untuk menstabilkan sekaligus menunjukkan perbedaan dan persamaan dengan etnis Tionghoa lainnya menjadi krusial untuk dipahami oleh khalayak. Bagaimana muslim Tionghoa di Surabaya melalui organisasi PITI, mengatasi permasalahan identitas mereka serta beragam tindakan peliyanan yang muncul dalam usaha untuk menjadi sama sekaligus berbeda ${ }^{7}$. Pembahasan perihal ini akan dikupas lebih pada bagian selanjutnya.

\section{PITI, Liyan dalam konsep Ukhuwwah Islamiyah}

'Apa yang sekilas terpikir ketika melihat seorang Tionghoa masuk masjid dan mengerjakan sholat? Yang pertama pasti 'nggumun', yang kedua penasaran yang terakhir tidak percaya. Saya sering mengalami hal-hal tersebut, bahkan tidak jarang malah mereka melihat saya dengan tatapan curiga.'

\section{-Abah Djoko -}

Berbeda, tidak sama maka bukan bagian dari kita. Hal tersebut menjadi sebuah pemahaman lumrah yang telah mapan dalam ranah sosial. Pada pernyataan informan yang dikutip di atas, menunjukkan adanya sebuah tindakan yang tanpa disadari memposisikan etnis Tionghoa muslim bukan sebagai bagian dari pemeluk agama Islam.

Munculnya tindakan peliyanan yang dilakukan oleh umat Islam lain menumbuhkan semangat bagi etnis Tionghoa muslim untuk mengkomunikasikan kediriiannya pada khalayak. Spirit itu kemudian diejawantahkan melalui pembangunan masjid yang berarsitektur Tionghoa, yakni masjid Muuhammad Cheng Hoo. Masjid Muhammad Cheng Hoo sendiri pertama kali dibangun di Surabaya pada tahun 2001. Bangunan masjid yang mengadaptasi unsur konstruksi budaya Tionghoa menjadi sebuah ikon yang mengkomunikasikan keberadaan etnis Tionghoa muslim. Seperti yang dibahas pada bagian sebelumnya, geliat etnis Tionghoa mulai muncul pada rejim kepemimpinan Gus Dur, dan mulai semarak menjadi 'ada' dalam konsep sosial.

Masjid Muhammad Cheng Ho sebagai tonggak awal etnis Tionghoa muslim mengkomunikasikan diri pada khalayak, mengedepankan budaya Tionghoa, bahkan nama

\footnotetext{
${ }^{7}$ Sama dengan muslim lainnya pada sisi liturgi dan keyakinan serat berbeda pada sisi akar budaya dan adat istiadat

${ }^{8}$ Nggumun ( Bahasa Jawa ) artinya heran
} 
masjid tersebut ditulis dengan huruf mandarin untuk mengukuhkan eksistensi budaya Tionghoa.

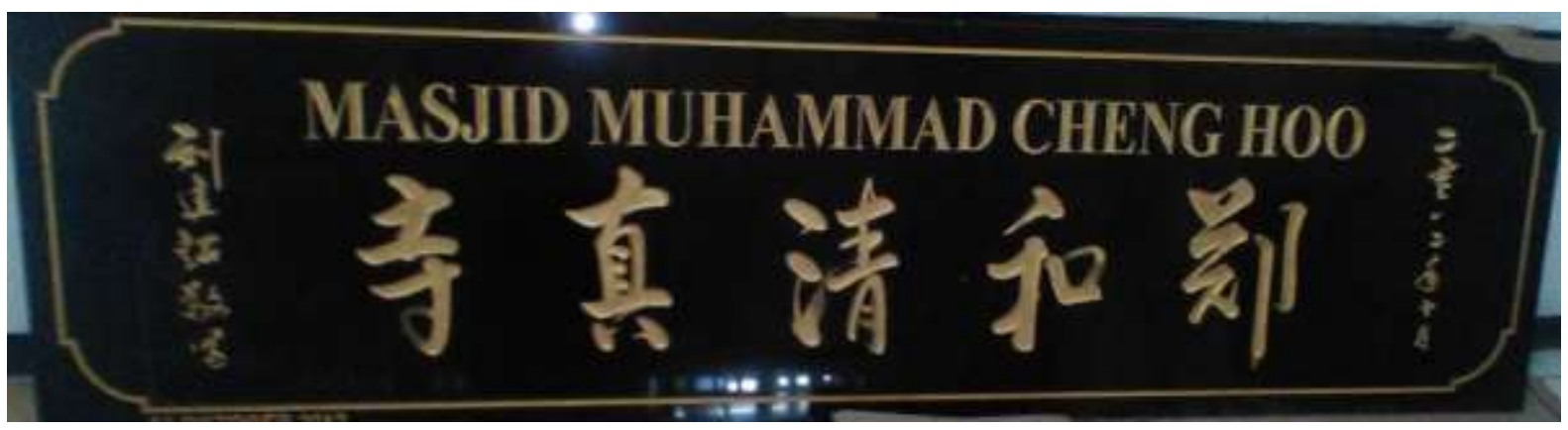

Papan nama Masjid Muhammad Cheng Hoo Surabaya

Upaya tersebut bahkan juga menular pada musli Tionghoa lain yang berada di luar wilyah Surabaya. Upaya tersebut kemudian memunculkan upaya pembangunan masjid Muhammad Cheng Hoo di seluruh wilayah Indonesia dengan PITI sebagai inisiatornya.

PITI Surabaya melalui masjid Cheng Hoo, tidak hanya memunculkan identitas kedirian etnis muslim Tionghoa, namun lebih dari itu. Melalui keberadaan masjid Muhammad Cheng Hoo, PITI mengharapkan ummat muslim lainnya dapat mengenal etnis muslim Tionghoa dengan melakukan ibadah di masjid ini. Seperti yang dipahami dalam pandangan ummat Islam, masjid adalah rumah ibadah yang meleburkan sekat sosial dan menjadi tempat netral dimana ummat mendatanginya untuk tujuan ibadah. Maka keberadaan masjid Muhammad Cheng Hoo, mampu mengakomodir bagaimana ummat dapat mengenali etnis Tionghoa muslim sebagai bagian dari pemeluk agama Islam.

PITI Surabaya, mengadopsi cara Nabi Muhammad saw., dalam memunculkan kerukunan antar pemeluk Islam dengan menjadikan masjud sebagai pusat kegiatan. Konsep memakmurkan masjid sekaligus menjalin kerukunan antar pemeluk Islam yang diadopsi oleh menjadi pintu masuk yang dinilai efektif untuk menjembatani perbedaan kultural yang muncul dalam usaha untuk membentuk persatuan ummat Islam. Seperti diketahui oleh ummat Islam, masjid memeiliki beberapa fungsi yang dapat menjadi pusat kegiatan baik kegiatan pendidikan, sosial maupun aktifitas lain yang tidak terdapat larangan untuk dilakukan di masjid.

Strategi komunikasi yang dilakukan oleh PITI Surabaya dengan melakukan pembangunan masjid yang merepresentasikan budaya ketionghoaan adalah upaya jitu yang 
memudahkan etnis Tionghoa muslim dikenali dan diterima oleh pemeluk Islam lainnya. Meski sebelumnya banyak dari pemeluk Islam lain berasumsi bahwa masjid Muhammad Cheng Hoo adalah sebuah klenteng (baca : bangunan masjid Muhammad Cheng Hoo mengadaptasi seni arsitektur Tionghoa yang kemudian diidentikkan sebagai rumah ibadah pemeluk keyakinan Tri Dharma). PITI Surabaya, berusaha untuk merubah stigma masyarakat - umumnya - dan umat muslim - khususnya - dengan melakukan beragam kegiatan yang berpusat di masjid Muhammad Cheng Hoo Surabaya.

' Masjid Muhammad Cheng Hoo ini memang bagi PITI adalah cara untuk menyatukan kami dengan umat Islam lainnya, sekaligus membuat mereka mengetahui keberadaan muslim Tionghoa, syukur - syukur mereka bisa menjalin persaudaraan erat dengan muslim Tionghoa.'

\section{-Abah Djoko -}

Usaha lain yang juga diupayakan oleh PITI Surabaya untuk menunjukkan eksistensi mereka baik sebagai bagian dari ummat Islam maupun bagian dari NKRI adalah dengan cara meresonansikan budaya etnis Tionghoa muslim dengan nilai-nilai yang dianggap luhur, baik oleh pemeluk Islam diluar etnis Tionghoa muslim maupun secara umum. Dalam usaha tersebut, PITI Surabaya mengusung sebuah konsep harmonisasi ummat Islam dan ummat keyakinan lain. Konsep harmonisasi ummat ini menjadi fokus yang diangkat oleh PITI Surabaya sehingga khalayak kemudian menemukan semangat kebangsaan yang juga diusung dalam konsep kerukunan ummat.

Menafikan hal-hal yang berbau politik, PITI Surabaya justru mengusung kerukunan yang harmonis melalui persamaan - persamaan yang dirasakan sebagai ummat muslim maupun sebagai bagian dari NKRI. Hal ini tidak terlepas dari adanya perasaan etnis Tionghoa muslim yang merasa menjadi bagian dari Indonesia. Adanya terminologi yang menyatakan bahwa etnis Tionghoa adalah pendatang, memposisikan mereka seolah bukan menjadi bagian dari bangsa ini. Jika ditilik dari sejarah etnis Tionghoa di Indonesia, sangat sulit ditemukan keturunan murni Tionghoa di Indonesia. Hal ini disebabkan karena telah terjadinya asimilasi baik dalam proses sosial maupun secara personal melalui perkawinan. Adanya anggapan bahwa etnis Tionghoa adalah kelompok diaspora di Indonesia juga tidak dapat dianggap sebuah anggapan yang salah.Gilroy (dalam Woodward, 2002 : 318) menyatakan bahwa etnis 
yang tidak memiliki akar budaya seperti etnis mayoritas di wilayahnya cenderung memunculkan sebuah 'gap'.

Sebagai etnis yang dianggap pendatang, sulit bagi orang Tionghoa - umumnya - dan Tionghoa muslim - khususnya - untuk mengekspresikan identitas mereka adalah bagian dari Indonesia. Usaha etnis Tionghoa muslim untuk menjadi bagian dari Indonesia yang mengusung harmonisasi juga muncul dalam tindakan mereka pada penggunaan batik di setiap kesempatan. PITI Surabaya, melalui informan menyatakan bahwa :

'Pemilihan baju batik untuk dikenakan dalam keseharian maupun untuk acara resmi, baik yang diselenggarakan oleh PITI maupun oleh pihak lain menyamankan kami. Kami merasa menjadi bagian dari Indonesia dengan menggunakan baju batik. Ini bukan karena kami tidak percaya diri jadi orang Tionghoa yang memakai baju yang menunjukkan ciri khas keTionghoaan, tapi lebih pada rasa menjadi Indonesia saja.'

\section{-Abah Djoko -}

Semangat untuk menjadi bagian dari Indonesia diwujudkan PITI dengan memposisikan diri sebagai sebuah wadah yang berfokus pada gerakan dan pelayanan sosial. Bahkan melalui PITI warga muslim Tionghoa dapat menggabungkan beberapa elemen sosial Tionghoa untuk bersama-sama membentuk wadah kerukunan etnis Tionghoa. Diadakannya kerjasama dalam wadah sosial etnis Tionghoa juga berdampak pada kemunculan etnis muslim Tionghoa dalam lingkungan Tionghoa sendiri. Kerjasama yang bersifat sosial dapat terjalin tanpa harus terbentur dengan sekat-sekat perbedaan keyakinan. Bagi muslim Tionghoa, etnis Tionghoa adalah bagian dari akar budaya mereka, sehingga bekerjasama dengan etnis Tionghoa lainnya pada ranah sosial mempermudah muslim Tionghoa untuk berbaur.

Salah satu hasil dari kerjasama dengan etnis Tionghoa lainnya dengan PITI Surabaya adalah berdirinya paguyuban warga Tionghoa Surabaya. Pada perkembangannya paguyuban tersebut dapat mendirikan sebuah klinik kesehatan dan fasilitas gedung serba guna di wilayah masjid Muhammad Cheng Hoo Surabaya. 


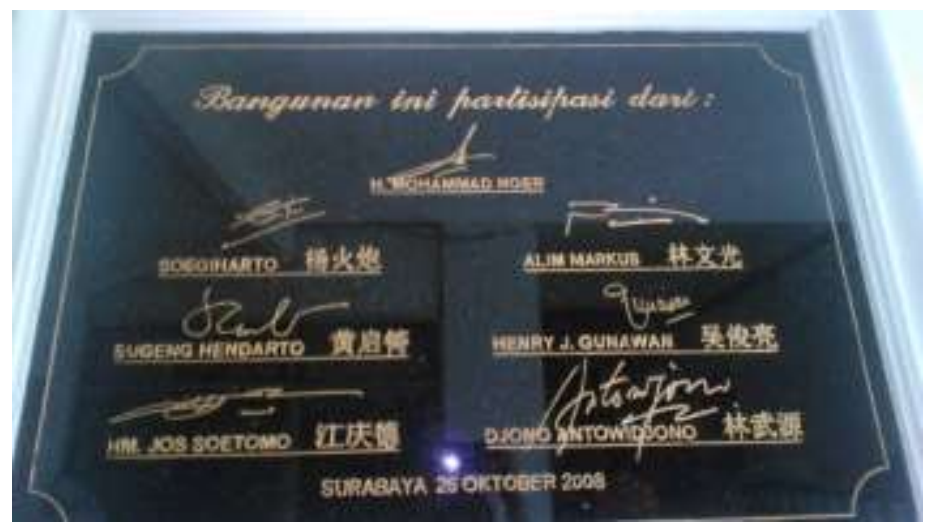

Plakat Partisipasi Pembangunan Gedung Fasilitas Sosial di sekitar masjid Cheng Hoo

Bangunan tersebut menjadi representasi dari terjalinnya hubungan antara etnis Tionghoa, yang tidak sebentar terjalin dengan PITI Surabaya.

Menurut informasi dari Abah Djoko, paguyuban warga Tionghoa ini menjembatani dan mampu menjadi wadah bagi perkumpulan etnis Tionghoa, baik muslim maupun nonmuslim untuk dapat menjalin persaudaraan. Paguyuban warga Tionghoa seolah menadi sebuah 'rumah besar' bagi warga etnis Tionghoa di wilayah Surabaya khususnya untuk saling berbagi dan mendukung satu sama lain. Proses kebersamaan dalam paguyuban ini bukan sebuah hal yang dengan mudah dapat terwujud. Banyak keadaan yang pada praksisnya menyulitkan PITI untuk menjalin kerjasama ini. Namun, tidak ada hasil yang menghianati upaya, demikianmenurut beliau, kerjasama yang terjalin sekarang sudah berdampak sangat signifikanbaik untuk etnis Tionghoa muslim maupun untuk PITI Surabaya.

Meski hubungan yang telah terjalin dengan beberapa pihak lain, seperti dengan etnis Tionghoa non-muslim, maupun dengan ummat muslim lainnya berjalan baik, namun secara umum penerimaan khalayak terhadap muslim Tionghoa masih cukup rendah. Hal tersebut muncul dari masih terbatasnya akses etnis Tionghoa muslim untuk terlibat aktif dalam wadah sosial kemasyarakatan di luar PITI maupun untuk tidak mendapatkan tindakan diskriminasi dari pihak lain (baca : ummat Islam selain muslim Tionghoa sendiri).

'Masih sulit untuk kami (baca : muslim Tionghoa) untuk benar-benar bisa berbaur dengan ummat Islam - khususnya - dan khalayak - umumnya -. Masih banyak dari ummat Islam sendiri yang tidak serta-merta menyambut kami dan menganggap kami adalah bagian dari mereka. Ini adalah pekerjaan besar yang masih menanti kami kedepannnya, Tidak hanya itu, permasalahan untuk melakukan pengkaderan bagi generasi muda muslim Tionghoa juga tidak mudah. Kami ( baca : pengurus PITI) sekarang bertambah tua, siapa lagi yang akan 
mengurus dan membesarkan PITI jika generasi mudanya semakin sibuk sendiri. Tentu ada kekhawatiran jika apa yang terjadi dulu (baca: peliyanan muslim Tionghoa), terjadi lagi bila tidak ada penerus bagi kami yang sekarang.'

\section{-Abah Djoko-}

Sebuah pekerjaan berat masih menanti PITI Surabaya - khususnya - dan muslim Tionghoa - umumnya - dalam upaya meredusi tindakan peliyanan atas diri mereka. Waktu yang dibutuhkan masih cukup panjang untuk mengedukasi dan menjalin hubungan baik dengan ummat Islam di wilayah Surabaya maupun Indonesia untuk dapat menciptakan sebuah harmoni keberagaman pemeluk Islam. Sejalan dengan Rutherford ( dalam Woodward, 2002 : 15) menyatakan bahwa proses untuk pembentukan identitas dan stabilisasi posisi identitas dalam ranah sosial adalah sebuah proses yang berjalin kelindan dengan konsepkonsep sosial, ekonomi bahkan politik dimana proses tersebut adalah sebuah proses panjang yang ha,pir seolah tak berujung.

Demikian juga dengan apa yang telah diusahakan oleh PITI Surabaya sebagai ujung tombak dalam meredusi berbagai tindakan peliyanan identitas mereka sebagai bagian dari muslim Tionghoa. Usaha mereka masih akan menempuh perjalanan panjang yang disertai oleh beragam aral untuk dapat membangun sebuah harmoni keberagaman dalam konsep ukhuwwah Islamiyah. 


\section{E. Kesimpulan.}

Mengacu pada penjabaran pada bagian sebelumnya dapat dipahami bahwa keberadaan etnis Tionghoa muslim masih dipandang sebagai kaum minoritas dan bahkan masih mengalami tindakan peliyanan, baik oleh ummat Islam sendiri maupun oleh etnis Tionghoa lainnya. Banyak yang belum mengetahui bahwa etnis Tionghoa muslim adalah sekelompok etnis yang bersinggungan dengan akar budaya Tionghoa dan di sisi lain juga merupakan bagian dari ummat Islam. Namun terjadinya represi pada keberadaan etnis Tionghoa sendiri - secara umum - dan etnis Tionghoa muslim - khususnya - di era rejim orde baru mengakibatkan visibilitas mereka hampir tidak muncul dalam ranah sosial.

Tidakan asimilasi total yang digagas oleh rejim penguasa Orde Baru kala itu memaksa mereka untuk untuk menanggalkan sebanyak mungkin identitas kultural mereka sebagai bagiandari etnis Tionghoa. Jika kondisi tersebut adalah sebuah keadaan yang menyulitkan bagi etnis Tionghoa, maka tindakan represi yang digagas pemerintah secara legal ( baca : diatur dalam instruksi presiden, maupun undang-undang lain yang mendukung tindakan represi tersebut) berdampak lebih berat bagi etnis Tionghoa muslim kala itu. Etnis Tionghoa muslim sebagai bagian minor dalam kelompok minoritas mengalami tindakan represi sekaligus penolakan pada saat yang bersamaan.

Meski menganut keyakinan Islam, namun pada masa represi, etnis Tionghoa muslim bahkan tidak mendapat dukungan, baik moril maupun sosial secara terbuka dari ummat Islam Indonesia kala itu. Tentu hal ini bukan tanpa sebab, tindakan dukungan terbuka pada etnis Tionghoa - umumnya - dan etnis Tionghoa muslim - khususnya - dianggap sebagai tindakan subversif yang bertujusn untuk melawan penguasa kala itu. Dengan kondisi yang menekan keberadaan mereka, etnis musli Tionghoa menjadi tidak teraba visibilatasnya di Surabaya khususnya - dan Indonesia - umumnya -.

Pergantian rejim penguasa pada era reformasi memberikan ruang bagi etnisTionghoa dan juga etnis Tionghoa muslim. Dengan dicabutnya perundangan yang bersifat diskriminatif membuat mereka mulai menggeliat dan mulai menunjukkan eksistensi kediriian mereka dalam ranah sosial. Setahun setelah dicabutnya perundangan yang bersifat diskriminatif bagi etnis Tionghoa, PITI Surabaya mencanangkan pembangunan masjid bernuansa Tionghoa pertama di Indonesia. Masjid Muhammad Cheng Hoo, sebagai titik awal usaha etnis Tionghoa muslim di Surabaya menunjukkan identitas mereka baik secara keyakinan maupun secara kultural. Dipilihnya pembangunan masjid sebagai ikon identitas muslim Tionghoa 
bukan tanpa alasan. Masjid bagi ummat Islam adalah sebuah pusat, baik sebagai pusat peribadatan maupun pusat peradaban dan interaksi sosial

Sedangkan pemilihan arsitektur bernuansa Tionghoa menjadi penanda akar budaya etnis Tionghoa muslim. Bahkan secara cermat PITI Surabaya menyematkan nama seorang laksamana besar yang kiprahnya telah diketahui, diakui dan warisannya masih dilestarikan hingga kini yakni, Laksamana Cheng Hoo (Zheng He). Cheng Hoo adalah representasi dari harmonisasi dari kerukunan etnis Tionghoa secara plural ( baca : baik suku maupun keyakinan). Melalui ekspedisi Cheng Hoo juga (Zheng He), jalur penyebaran Islam menjadi lebih luas dan menyentuh wilayah-wilayah yang terpisah ratusan mil dari akar wilayah Islam yaitu, Timur Tengah. Representasi yang dimunculkan PITI Surabaya dengan menggabungkan baik unsur yang teranggit dengan akar budaya maupun kultur Islam sendiri memberikan sebuah respon positif oleh khalayak.

Proses komunikasi yang dipilih melalui pembangunan masjid dan fokus aktifitas di bidang sosial mengantarkan PITI Surabaya untuk menjalin hubungan, baik sosial maupun kultural dengan sesame etnis Tionghoa dan ummat Islam Surabaya. Upaya tersebut setidaknya dapat meredusi tindakan peliyanan yang dialamatkan pada kediriian etnis Tionghoa muslim, khususnya di Surabaya. Jalan yang harus ditempuh PITI Surabaya dalam upaya meniadakan peliyanan yang mereka alami masih sangat jauh dari kata selesai. Hal tersebut disebabkan karena proses mengedukasi ummat Islam di wilayah Surabaya masih berjalan hingga kini, dan diantara berjalannya proses tersebut etnis Tionghoa muslim di Surabaya setidaknya masih harus bersabar dan mengupayakan tindakan untuk menafikan adanya diskriminasi atas identitas mereka. 


\section{Daftar Pustaka}

Alasuutari, Perrti. 1999. Rethinking the Media Audience. London: Sage Publication

Ang, Ien. 1991. Desperately Seeking the Audience, London/New York: Routledge. Ang, Ien. 2000. “'Identity blues.”In Without guarantees: In honour of Stuart Hall, edited by Paul Gilroy, Lawrence Grossberg, and Angela McRobbie, 1-13. London: Verso. Ang, Ien. 2005. On Not Speaking Chinese: Living Between Asia and the West. London \& New York: Routlege.

Ang, Ien. 2003. "Together-in-Difference: Beyond Diaspora, into Hibriditas". Asian Studies Review. Vol. 27. No.2.

Budianta, M. (2004) Identitas dalam masyarakat multibudaya [Identity in multicultural society]. In H. Soesastro, J. Kristiadi and A. Priyadi (Eds). Budi dan Nalar: 70 Tahun Harry Tjan Silalahi [Knowledge and thoughts: 70 year old Harry Tjan Silalahi] (Jakarta, Centre for Strategic and International Studies), pp. 601-612.

Chua, Christian. 2004. "Defining Indonesian Chineseness under the New Order". 3 Volume 34. Journal of Contemporary Asia.465-79.

Chunjiang Fu, Choo Yen Foo, Yaw Hoong Siew. 2005. The great explorer Cheng Ho. Ambassador of peace. Asiapac Books

Dawis, Aimee. 2010. Orang Indonesia Tionghoa : Mencari Identitas. Gramedia, Jakarta

Kathryn, Woodward. 2002. Identity and Difference. Sage Publication

Kennedy, Hugh. 2007. The Great Arab Conquest. Da Capo Press

Lindsey, T. 2005. Chinese Indonesians: Remembering, distorting, forgeting. Singapore: Institute of Southeast Asian Studies.

PITI Surabaya. 2008. Sekilas tentang Masjid Muhammad Cheng Hoo: cetakan ke - 8. Yayasan Masjid Muhammad Cheng Hoo

Retnaningsih, H. 2012. “Tahun baru Imlek dan upaya pembauran di Indonesia.” Info singkat kesejahteraan sosial. Vol. IV, No. 02/II/P3DI/Januari/2012 


\section{Sumber Lain}

Disertasi Liliek Soelistyo. 2015. RESEPSI ORANG TIONGHOA TERHADAP TAYANGAN KETIONGHOAAN DI LIMA STASIUN TELEVISI SWASTA, Kajian

Budaya dan Media, Sekolah Pascasarjana Universitas Gadjah Mada

Encyclopedia Jakarta

Kumpulan Peraturan Perundangan dalam Instruksi Presiden Republik Indonesia

Laman batik dan blogspot.com diakses pada 12 Agustus 20017

Undang-undang

Zheng He dalam Wikipedia 